\title{
ACUTE AND CHRONIC TOXICITY OF SEDIMENT SAMPLES FROM GUANABARA BAY (RJ) DURING THE RAINY PERIOD*
}

\author{
Luciane Alves Maranho ${ }^{l, * *}$, Ilene Matanó Abreu ${ }^{2}$, Ricardo Erthal Santelli ${ }^{2}$, Renato Campelo Cordeiro ${ }^{2}$, Abílio \\ Soares-Gomes ${ }^{3}$, Lucas Buruaem Moreira ${ }^{4}$, Rodofley Davino Morais ${ }^{5}$ and Denis Moledo de Sousa Abessa ${ }^{1,4}$
}

${ }^{1}$ Universidade Estadual Paulista "Júlio de Mesquita Filho" - UNESP

Campus do Litoral Paulista -São Vicente

(Praça Infante Dom Henrique, s/n, 11330-900 São Vicente, SP, Brasil)

${ }^{2}$ Universidade Federal Fluminense

Programa de Geoquímica

(Outeiro de São João Batista, s/n, 24020-007 Niterói, RJ, Brasil)

${ }^{3}$ Universidade Federal Fluminense

Instituto de Biologia. Depto. de Biologia Marinha

(Outeiro de São João Batista, s/n, 24001-970 Niterói, RJ, Brasil)

${ }^{4}$ Universidade Federal do Ceará

Instituto de Ciências do Mar. Labomar

(Av. Abolição, n 3207, 60165-081 Fortaleza, CE, Brasil)

${ }^{5}$ Universidade Federal do Paraná

Laboratório de Biogeoquímica Marinha, Centro De Estudos Do Mar (CEM)

(Av. Beira-mar, s/n, 83255-000 Pontal do Paraná, PR, Brasil)

**Corresponding author: lmaranho@gmail.com

\begin{abstract}
A B S TR A C T
Guanabara Bay is a marine-estuarine environment of high ecological and socio-economic importance, subject to a variety of environmental impacts. Sediment is the eventual repository for most substances introduced into water bodies and may, therefore, provide an integrated measure of the environmental quality, which can be assessed by many different approaches. In this project, the quality of sediments from Guanabara Bay was evaluated by the ecotoxicological approach: whole-sediment toxicity tests, using Tiburonella viscana, and porewater, elutriate and sediment-water interface chronic toxicity tests, using embryos of Lytechinus variegatus, were applied. Sediments were collected at 14 sampling stations, distributed across the bay. Chronic tests showed significant toxicity in most of the sediment samples. Sediments from stations $1,2,3,6,8,10,11,12$ and 15 showed acute toxicity as well. The results of the different tests were well correlated, and their integration showed that the sediments analyzed were considered unsuitable for aquatic life, resulting in the environmental degradation of Guanabara Bay. In this context, the control of pollution sources and multi-purpose management are required to improve the environmental quality.
\end{abstract}

\section{RESUMO}

A Baía de Guanabara é um ambiente marinho-estuarino de grande relevância ecológica e sócioeconômica, e sujeita a uma ampla gama de impactos ambientais. O sedimento é o principal destino para a maioria das substâncias introduzidas nos corpos d'água, podendo fornecer uma medida integrada da qualidade ambiental, a qual pode ser avaliada por várias abordagens. Neste projeto, a qualidade de sedimentos da Baía de Guanabara foi por uma abordagem ecotoxicológica, por meio de testes de toxicidade aguda de sedimento integral, utilizando Tiburonella viscana, e testes de toxicidade crônica de água intersticial, elutriato e interface sedimento-água, utilizando embriões de Lytechinus variegatus. Os sedimentos foram coletados em 14 estações de amostragem. Nos testes crônicos houve efeitos significativos na maioria das amostras, enquanto os sedimentos coletados nas estações $1,2,3,6,8,10$, 11, 12 e 15 apresentaram também toxicidade aguda. Houve grande concordância entre os resultados dos diferentes testes, e sua integração mostrou que os sedimentos analisados encontram-se inadequados à vida aquática, indicando degradação ambiental na baía da Guanabara. Nesse contexto, o controle das fontes poluidoras e o gerenciamento dos múltiplos usos da baía devem ser implementados, no sentido da melhora da qualidade ambiental.

Descriptors: Bioassays, Tiburonella viscana, Lytechinus variegatus, Sediment, Toxicity, Guanabara Bay. Descritores: Boensaios, Tiburonella viscana, Lytechinus variegatus, Sedimento, Toxicidade, Baía de Guanabara. 


\section{INTRODUCTION}

Guanabara Bay (GB) is an important Brazilian estuary of high socio-economic and ecological value. However, GB is subjected to a variety of anthropogenic impacts, such as the presence of landfills, the increased sediment loading due to continental erosion, the destruction of habitats such as beaches, lagoons and mangrove swamps (AMADOR, 1997), and the contamination originating from the second largest industrial park and commercial port in the country. The vicinity of the GB is also occupied by oil terminals and refineries, airports, shipyards, naval bases and a large number of marinas (KJERFVE et al., 1997).

Some anthropogenic events, such as dredging and channeling, have accompanied the development of the region, which ultimately has increased the sediment and nutrient transport to the bay. High nutrient concentrations are found in the internal areas, such as the northwestern margin (PARANHOS et al., 1998; RIBEIRO; KJERFVE, 2002). The severe eutrophication has made GB waters unsuitable for recreational use and led to a decline in fisheries of up to $90 \%$ in recent years (CARREIRA et al., 2004; MARQUES-JUNIOR et al., 2006). Despite the intense urbanization around most of GB, its northeastern area is still surrounded by mangroves, which are legally protected by the Guapimirim Environmental Protection Area.

As previously mentioned, large amounts of metals and organic pollutants are discharged into the bay, and most of them accumulate in the sediment. The highest metal concentrations were found in the northwest portion of the GB, close to the mouth of a polluted river and a large oil refinery (REDUC) (BAPTISTA-NETO et al., 2006). A second "hot spot" is the Rio de Janeiro Port (BAPTISTA-NETO et al., 2006; VILELA et al., 2004), situated on the western side of GB. Jurujuba Sound, at the southeastern end of the GB, may be considered a third "hot spot" (MARQUES-JUNIOR et al., 2006; BAPTISTANETO et al., 2000). Furthermore, high lead $(\mathrm{Pb})$ concentration in the middle of GB is likely related to the presence of an oil terminal (BAPTISTA-NETO et al., 2006). Large oil spills which occurred between 1998 and 2002 have aggravated the pollution in GB, affecting the resident biota and its environmental quality (MENICONI et al., 2002; KFOURI et al., 2003).

Sediment is the main repository for most of the substances introduced into water bodies (ADAMS et al., 1992). Thus, sediment quality assessment becomes a primary issue for the management of aquatic environments. In this context, ecotoxicological tests are intended to verify and understand the effects of biologically active substances on organisms and ecosystems (ZAKREWSKI, 1991). To estimate correctly the ecotoxicological potential of contaminated sediments it is necessary to assess the main exposure routes of contaminants, which are: whole sediment (ABESSA et al., 2008), interstitial water (CARR; NIPPER, 2003), elutriate (NIPPER, 1997) and sediment-water interface (CESAR et al., 2004).

Despite their major socio-economic and environmental importance, the toxicity of the sediments of GB is relatively little studied and the functioning of its ecosystem is poorly understood. Thus, further study of ecotoxicological, ecological and chemical aspects is called for, not only to assess the environmental quality of GB, but also to derive reference values and quality guidelines in order to develop proper framework tools to manage the area within an environmentally sustainable perspective. The objective of this project was to evaluate the sediment quality of Guanabara Bay, Rio de Janeiro, during the rainy season, by means of acute and chronic toxicity tests. Secondly, information was obtained to aid in identifying the critical areas of the Bay.

\section{Materials And Methods}

\section{Study Area}

Fourteen sampling stations, distributed across Guanabara Bay, were established (Figure 1). The campaign was conducted in March 2008, during the rainy season.

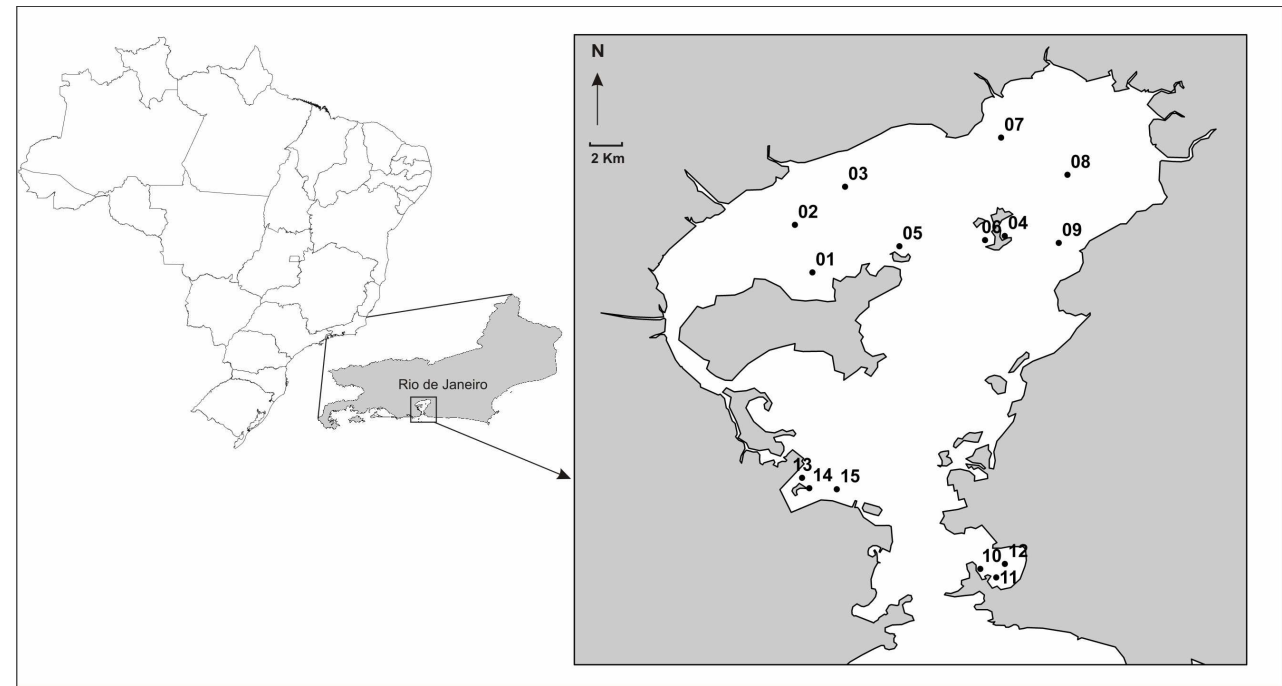

Fig. 1. Map of Guanabara Bay, indicating the sampling stations. 
Sediments were collected with a Birge Ekman dredge. The samples were transferred to plastic bags and immediately cooled. Sediment samples were kept at $4^{\circ} \mathrm{C}$ in the laboratory until the beginning of the tests.

\section{Granulometric Analysis}

Sediment samples were dried, homogenized and digested with $\mathrm{HNO}_{3}$, in accordance with method 3051 (U.S. EPA, 1994). The particle size distribution was measured by a laser particle analyzer model CILAS 1064.

Physical-Chemical Analysis

For the chronic toxicity tests, the following parameters were measured in the liquid phases extracted from the sediments: $\mathrm{pH}$, salinity, temperature, dissolved oxygen and total ammonia nitrogen. For the acute toxicity, most of these parameters were measured in the overlying water in the test chambers, with the exception of total ammonia nitrogen.

\section{Amphipod Toxicity Test}

Whole sediment toxicity tests (WS) were conducted using the burrowing amphipod Tiburonella viscana (Thomas; Barnard, 1983) as the test-organism. Both internal control sediment and test-organisms were collected at Engenho d'Água beach (Ilhabela, São Paulo, Brazil). The amphipods were transported to the laboratory and acclimated for 48 hours.

The toxicity test was performed following the protocol described by SWARTZ et al. (1985) for Rhepoxinius abronius and adapted for T. viscana by MELO; ABESSA (2002). The bioassay consisted of exposing the amphipods to the test-sediment for a period of 10 days, and evaluating the survival rates at the end of the experiment.

The replicates were kept under constant aeration and lighting, and the test was maintained in a temperature controlled room $\left(25 \pm 2^{\circ} \mathrm{C}\right)$. At the end of the exposure period, the content of each replicate was sieved and the surviving organisms were counted. The mortality rates were recorded; missing individuals were considered as dead.

\section{Sea-urchin Embryo-Larval Toxicity Tests}

Short-term chronic toxicity tests with the sea-urchins were performed in accordance with the international guidelines (U.S. EPA, 1995; ENVIRONMENT CANADA, 1999), with minor adaptations (CETESB, 1999).

The interstitial water (PW) was obtained by the suction method (WINGER; LASIER, 1991). After extraction, PW samples were centrifuged at 4000 RPM for 15 minutes. The supernatant was separated for the ecotoxicological analysis. The extracted samples were stored in polyethylene bottles and frozen until use.

Elutriate samples (ELU) were obtained by mixing a composite sample of sediment and water dilution (filtered sea water) in the proportion of 1:4 (U.S. EPA, 1991).

For both PW and ELU tests, three dilutions were prepared $(25,50$ and $100 \%)$ by diluting the whole samples in clean filtered seawater. Four replicates were prepared for each dilution.

The sediment-water interface test (SWI) was prepared according to the procedure described by Anderson et al. (2001) and adapted by Cesar et al. (2004). Three replicates were prepared for each station and for two different types of control: dilution water and dilution water plus filter-net, called control-net, which was used to determine whether the net would have any effect on embryo development.

For these three tests, the embryo-larval development of newly fertilized eggs of the sea-urchin Lytechinus variegatus (Lamarck, 1816) was evaluated. Adults of $L$. variegatus were collected on Palmas Island (Santos, SP, Brazil), rapidly transported to the laboratory, and maintained under controlled conditions, in accordance with the protocol NBR 15350 established by the Brazilian Association for Technical Standards (ABNT, 2006).

The spawning was induced by osmotic shock, with the injection of $1-3 \mathrm{ml}$ of $\mathrm{KCl}(0.5 \mathrm{M})$ into the adult sea-urchins' abdominal cavity. The gametes of each spawned animal were separated. After the separation and the analysis of the gametes of different animals, fertilization was initiated in the laboratory by adding 1-2 $\mathrm{ml}$ of sperm solution to the ovule solution. Then the solution of freshly fertilized eggs was added to each replicate. The tests were held in environmental chambers for an $8: 16 \mathrm{~h}$ (light/dark) period and at temperature of $20 \pm 2^{\circ} \mathrm{C}$. When $80 \%$ of the control larvae reached the pluteus stage (after approximately 24 to 28 hours) the embryos were fixed by adding $4 \%$ neutralized formalin to the test chambers. The above procedure, described by Prósperi; Araújo (2002), was the same for all the chronic tests.

\section{Statistical Analysis}

Data were first checked for normality by Shapiro Wilk's and Bartlett tests, respectively. The homogeneity of variances (homoscedasticity) was checked by the F-test. After confirmation of homoscedasticity and normality, Student's t-test (ZAR, 1996) was applied to compare the samples with their respective controls. Toxstat 3.5 program (WEST INC,; GULLEY, 1995) was used for these analyses.

In the acute toxicity test, the data for each sample was compared to the control and to the other samples. For the analysis of chronic toxicity data, the Least Significant Difference (LSD) was also taken into consideration, by the use of the bioequivalence constant $r=0.86$ (BERTOLETTI et al., 2007).

The resulting data were interpreted in the light of the toxic effects due to the $\mathrm{NH}_{3}$, similarly to the approach applied by Abessa et al. (2008) to the external portion of the Santos Bay. To avoid errors of interpretation, the toxicity data were reevaluated, not only for statistical differences but also as to whether non-ionized ammonia may have been present at concentrations high enough to have been a possible confounding factor (CARR et al., 2006). When the samples' results were significantly different from the controls', but showed levels of $\mathrm{NH}_{3}>0.05 \mathrm{mg} / \mathrm{l}$, they were considered to have been influenced by this confounding factor and were designated as significantly different (SD). Based on the classification into categories of diagnosis for the $L$. 
variegatus test proposed by CETESB (2007), the samples that were significantly different from control, but exhibited embryonic development rates close to those of control (> than $80 \%$ ), were classified as nontoxic.

\section{RESULTS}

\section{Sediment Grain Size}

The majority of stations presented sediments composed of mixtures of sands and silts (Fig. 2). Previous studies had characterized the sediments from Engenho d'Água beach, composed predominantly of very fine and fine sands (ABESSA et al., 2005, 2008).

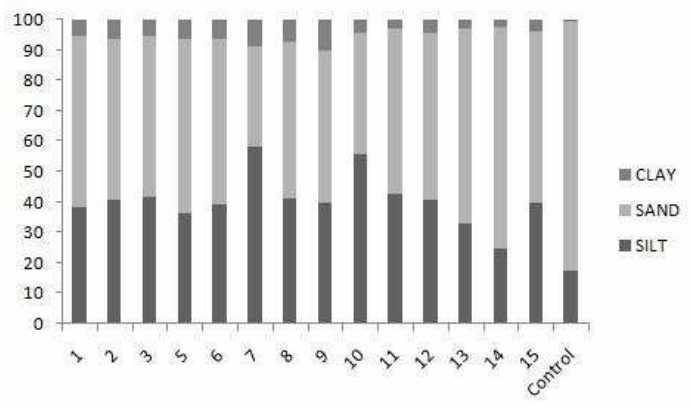

Fig. 2. Distribution of clays, silts and sands in the sediments from each sampling station.

\section{Toxicity Tests}

Guanabara Bay is characterized as a coastal polluted and eutrophic area (LOURENÇO et al., 2006), where the occurrence of high concentrations of ammonia, from natural and anthropic origins, can be expected. Under such conditions, ammonia may confound the toxicity tests results, especially if unionized ammonia $\left(\mathrm{NH}_{3}\right)$ is present in high concentrations (CARR et al., 2006; SARDA; BURTON, 1995). However, in this study, the levels of non-ionized ammonia did not seem to have influenced the toxicity data in the liquid phases, because the concentrations were relatively low. The ammonia percentage in relation to the total nitrogen ranged between $0.96 \%$ at station 7 (near the Guapimirim EPA) and $10.84 \%$ in the northwest portion (station 2), which receives disposal of domestic sewage.

For the PW test, all stations were significantly different from the control, independently of the dilution level (Table 1).

Considering that the dilutions are used to minimize the interference of un-ionized ammonia, the PW toxicity results indicated that the samples from the stations $7,8,9,10,11,12$ and 15 were considered toxic. The samples from stations $1,2,5$ and 14 were considered as SD, due to the impossibility of distinguishing whether the effects were caused by contaminants or by the high ammonia levels. Samples from stations $6,7,12$ and 13 were significantly different from the control, had low ammonia concentrations, and the embryological development rates were $>80 \%$, thus they were considered as nontoxic according to the state environmental agency criteria (CETESB, 2007). Station 3 was also considered non-toxic.

In the elutriate test, only the sample from station $2(100 \%)$ showed a high concentration of unionized ammonia (Table 2). This station is located in the northwest of the GB (Fig. 1).

Table 1. Results of the porewater toxicity test, with the normal embryonic development of L. variegatus and the unionized ammonia concentrations in each sample $(*=$ significantly different from the control, $\mathrm{p}<0.05)$. Gray cells indicate influence of $\mathrm{NH}_{3}$ on the observed effect.

\begin{tabular}{|c|c|c|c|c|c|c|}
\hline \multirow{2}{*}{ Stations } & \multicolumn{3}{|c|}{$\%$ Larvae development } & \multicolumn{3}{|c|}{$\mathrm{NH}_{3}(\mathrm{mg} / \mathrm{L})$} \\
\hline & $100 \%$ & $50 \%$ & $25 \%$ & $100 \%$ & $50 \%$ & $25 \%$ \\
\hline 1 & $0 *$ & $0^{*}$ & $0 *$ & 0.52 & 0.26 & 0.13 \\
\hline 2 & $0 *$ & $0^{*}$ & $0 *$ & 1.00 & 0.50 & 0.25 \\
\hline 3 & $0 *$ & $0^{*}$ & 85.5 & 0.21 & 0.11 & 0.06 \\
\hline 5 & $0^{*}$ & $0^{*}$ & $0 *$ & 0.40 & 0.20 & 0.10 \\
\hline 6 & $0^{*}$ & $0^{*}$ & $91.5^{*}$ & 0.14 & 0.07 & 0.04 \\
\hline 7 & $0^{*}$ & $0^{*}$ & $90.3^{*}$ & 0.07 & 0.04 & 0.02 \\
\hline 8 & $0^{*}$ & $0^{*}$ & $0 *$ & 0.06 & 0.03 & 0.02 \\
\hline 9 & $0^{*}$ & $0 *$ & $2.8^{*}$ & 0.14 & 0.07 & 0.04 \\
\hline 10 & $0^{*}$ & $0^{*}$ & $77.3^{*}$ & 0.04 & 0.02 & 0.01 \\
\hline 11 & $0^{*}$ & $0^{*}$ & $76.5^{*}$ & 0.04 & 0.02 & 0.01 \\
\hline 12 & $0 *$ & $0^{*}$ & $87.3^{*}$ & 0.06 & 0.03 & 0.02 \\
\hline 13 & $0^{*}$ & $0^{*}$ & $87.8^{*}$ & 0.17 & 0.09 & 0.05 \\
\hline 14 & $0^{*}$ & $0^{*}$ & $0 *$ & 0.21 & 0.11 & 0.06 \\
\hline 15 & $0^{*}$ & $0^{*}$ & $0^{*}$ & 0.16 & 0.08 & 0.04 \\
\hline Control & & 95 & & 0.00 & 0.0 & 0.0 \\
\hline
\end{tabular}


Table 2. Results of the elutriate toxicity tests, with the normal embryonic development of L. variegatus and the unionized ammonia concentrations in each sample $(*=$ significantly different from control, $\mathrm{p}<0.05)$. Gray cells indicate influence of $\mathrm{NH}_{3}$ on the observed effect.

\begin{tabular}{ccccccc}
\hline \hline \multirow{2}{*}{ Stations } & \multicolumn{3}{c}{$\%$ Larvae development } & \multicolumn{3}{c}{$\mathrm{NH}_{3}(\mathrm{mg} / \mathrm{L})$} \\
& $100 \%$ & $50 \%$ & $25 \%$ & $100 \%$ & $50 \%$ & $25 \%$ \\
\hline 1 & $0^{*}$ & $90.8^{*}$ & $93.7^{*}$ & 0.02 & 0.01 & 0 \\
2 & $0^{*}$ & $0^{*}$ & $13^{*}$ & 0.05 & 0.02 & 0.01 \\
3 & $0^{*}$ & $89.8^{*}$ & $90.8^{*}$ & 0.02 & 0.01 & 0.01 \\
5 & $0^{*}$ & $92^{*}$ & $89.3^{*}$ & 0.01 & 0.01 & 0 \\
6 & $89^{*}$ & $93.5^{*}$ & $87.5^{*}$ & 0 & 0 & 0 \\
7 & $0^{*}$ & $93^{*}$ & $88^{*}$ & 0 & 0 & 0 \\
8 & $0^{*}$ & $93^{*}$ & $91.5^{*}$ & 0.02 & 0.01 & 0.01 \\
9 & $0^{*}$ & $93^{*}$ & $92.3^{*}$ & 0.01 & 0.01 & 0 \\
10 & $0^{*}$ & $89.7^{*}$ & $91^{*}$ & 0.01 & 0.01 & 0 \\
11 & $0^{*}$ & $89.3^{*}$ & $88^{*}$ & 0.01 & 0.01 & 0 \\
12 & $90.5^{*}$ & $86.8^{*}$ & $86.3^{*}$ & 0 & 0 & 0 \\
13 & $0^{*}$ & $89.8^{*}$ & $93^{*}$ & 0.01 & 0.01 & 0 \\
14 & $0^{*}$ & $91.8^{*}$ & $90.3^{*}$ & 0.01 & 0.01 & 0 \\
15 & $0^{*}$ & $0^{*}$ & $89^{*}$ & 0.03 & 0.02 & 0.01 \\
Control & & 95 & & 0 & 0 & 0 \\
\hline
\end{tabular}

In this test, most of the samples were considered toxic, except those from stations 6 and 12 , which were considered non-toxic because the embryo larval development was higher than $80 \%$.

In the SWI test, the rate of embryonic development in the controls showed acceptable values and low standard deviation. The majority of the samples were considered significantly toxic by this test (Fig. 3), excepting those collected at stations 2 and
15, which were considered SD, because of the high concentration of $\mathrm{NH}_{3}$.

The acute toxicity test result is shown in Figure 4. The sediment-control from Ilhabela data exhibited low mortality rate. According to the statistical analysis carried out, the survival rates of amphipods exposed to sediments from stations 1, 2, 3, $6,8,10,11,12$ and 15 were statistically different from the control group, thus such samples were considered toxic.

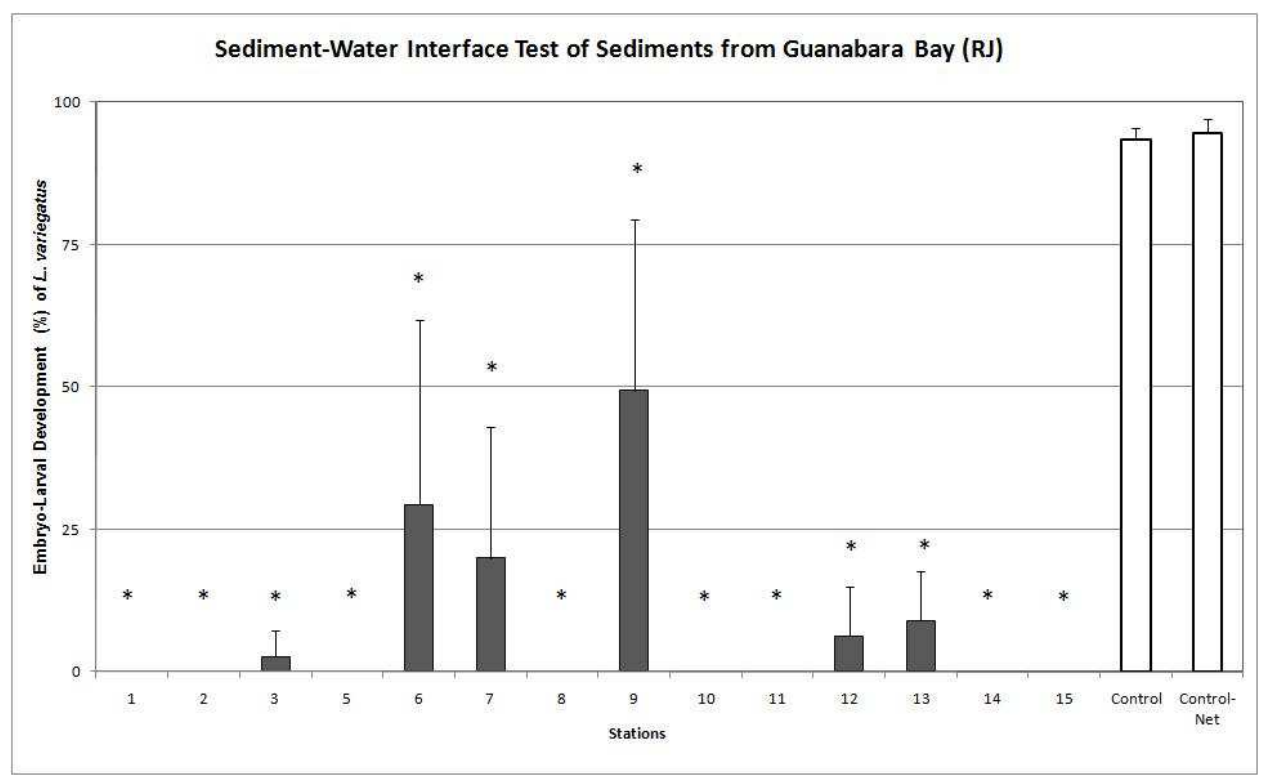

Fig. 3. Sediment-water interface toxicity in samples collected in Guanabara Bay, during the rainy period $(*=$ significantly different from the control, for $\mathrm{p}<0.05$ ). 


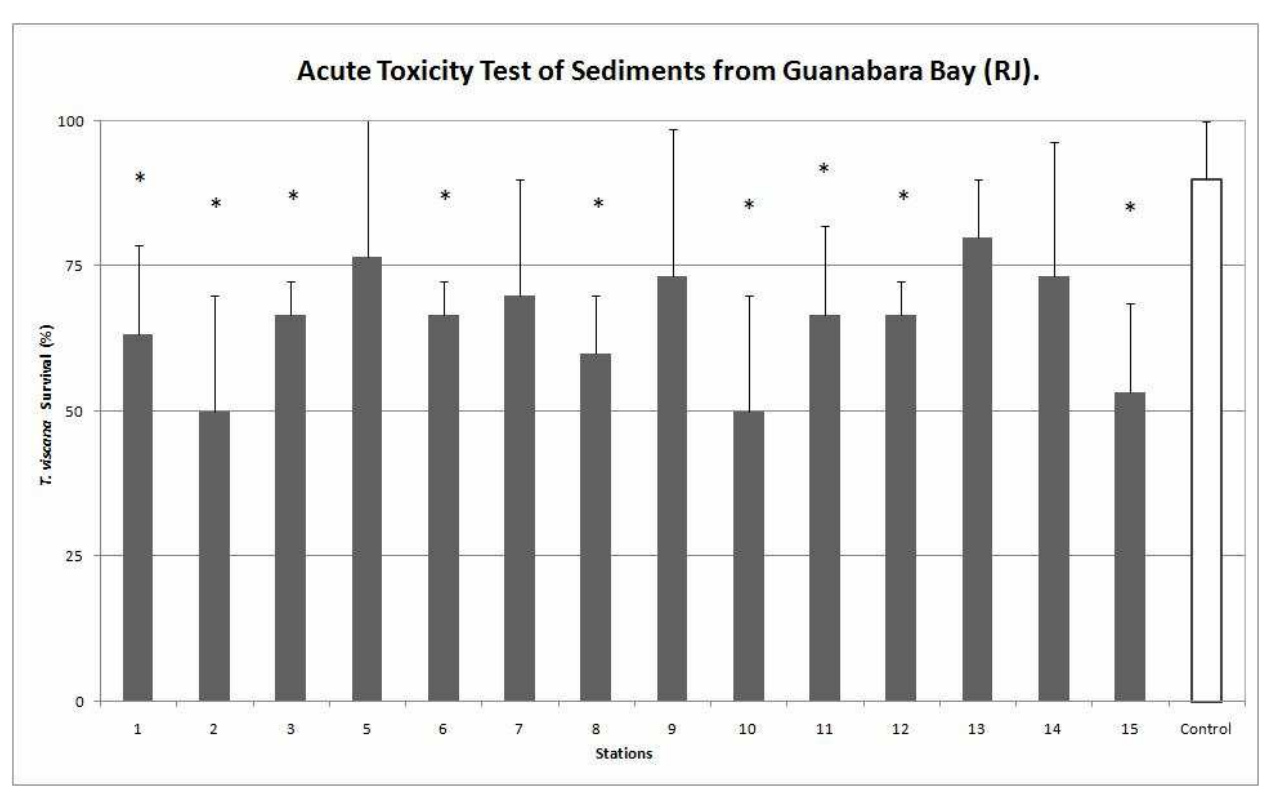

Fig. 4. Whole-sediment toxicity in samples collected in Guanabara Bay, during the rainy period $(*=$ significantly different from the control, for $\mathrm{p}<0.05$ ).

\section{Discussion}

The results of the different toxicity tests were correlated, since the interference of non-ionized ammonia was not significant for most of the samples (Table 3). Significant toxicity was observed in SWI and PW tests, but for stations 1, 2, 5 and 14, the effect was confounded by ammonia interference. However, samples 1 and 2 exhibited acute toxicity, together with the sediments from stations $3,6,8,10,11,12$ and 15 . Thus, the results indicated that the environmental conditions were clearly unsuitable for aquatic life during the rainy season, as most of the samples were toxic. Moreover, the ELU tests showed that most samples were toxic (excepting those from stations 6 and 12), demonstrating that the sediments have the potential to transfer toxicity to the water column. Considering an overview for SWI, ELU and PW, sediments from all the stations showed chronic toxicity during the rainy season.

According to the location of the stations and similarity among the results for all of the toxicity tests, the GB can be subdivided into four sectors, which represent the range of environmental degradation observed among the stations studied in GB:

- Southwest Sector: this is the region near Jurujuba Sound, which included the stations 10, 11 and 12 . Acute toxicity was observed at all stations and, in general, sediments from these stations showed chronic toxicity. The presence of the Icaraí submarine sewage outfall in this sector is likely to be contributing significantly to the ammonia "input". Previous studies had characterized this area as eutrophic (MARQUESJUNIOR et al., 2006).

Since the construction of the Rio-Niterói Bridge, the watershed adjacent to Jurujuba Sound has suffered extensive deforestation and rapid urbanization, which has led to increased coastal erosion, as well as to the dumping of garbage and sewage into the local waters. Nowadays, the depth ranges between 7 and 3 meters, affecting the local hydrodynamics. There is a possibility of human contamination directly associated with the recreational use, and food contamination arising from the fishing and shellfish cultivation practiced in this area of GB. The bioaccumulative metals, such as $\mathrm{Cr}, \mathrm{Cu}, \mathrm{Pb}, \mathrm{Ni}$ and $\mathrm{Zn}$, were recently found in high concentrations in sediments from this area (BAPTISTA-NETO et al., 2000; 2005). Metal levels in Jurujuba Sound sediments are comparable to those of other highly polluted coastal areas in the world (BAPTISTANETO et al., 2006; VILELA et al., 2004) such as San Francisco Bay in the United States (PARANHOS et al., 1998).

- Southeast Sector: this region is closer to the RioNiterói Bridge and Rio de Janeiro Port and includes the stations 13, 14 and 15. Sediments from these stations were considered chronically toxic in at least two tests. Sediments collected at station 15 also showed acute toxicity. Regarding the possible sediment impacts in the water column, which may be estimated by the results of the ELU and SWI bioassays, it is clear that any activity that would remove or re-suspend sediments in this area should be well planned and carried out with caution, because the conditions for the transfer of the sediment contaminants from the sediment to the water column exist.

- Northwest Sector: this sector comprises the stations located between Governador Island and the mainland (Stations 1, 2, 3 and 5). Stations 1, 2 and 3, closer to REDUC, are permanently influenced by the effluent and atmospheric processes, and they, especially the mangrove area (MACIEL-SOUZA et al., 2006), were recently impacted by oil spills. High levels of coprostanol (an indicator of fecal contamination) were recently reported in the region near stations 2 and 3, and were the highest anywhere in the bay (CARREIRA et al., 2004). These sediments also showed acute toxicity. 
Table 3. Summary of toxicity test data for sediment samples from Guanabara Bay: qualitative results after the data interpretation, considering the statistical analysis and the NH3 interference (SD = significantly different from the control; NT = non toxic).

\begin{tabular}{|c|c|c|c|c|}
\hline \multirow{2}{*}{ Stations } & \multicolumn{3}{|c|}{ Toxicity Tests } & \multirow[b]{2}{*}{ WS } \\
\hline & PW & ELU & SWI & \\
\hline 1 & SD & Toxic & Toxic & Toxic \\
\hline 2 & SD & Toxic & SD & Toxic \\
\hline 3 & NT & Toxic & Toxic & Toxic \\
\hline 5 & SD & Toxic & Toxic & NT \\
\hline 6 & NT & NT & Toxic & Toxic \\
\hline 7 & Toxic & Toxic & Toxic & NT \\
\hline 8 & Toxic & Toxic & Toxic & Toxic \\
\hline 9 & Toxic & Toxic & Toxic & NT \\
\hline 10 & Toxic & Toxic & Toxic & Toxic \\
\hline 11 & Toxic & Toxic & Toxic & Toxic \\
\hline 12 & Toxic & NT & Toxic & Toxic \\
\hline 13 & NT & Toxic & Toxic & NT \\
\hline 14 & SD & Toxic & Toxic & NT \\
\hline 15 & Toxic & Toxic & SD & Toxic \\
\hline
\end{tabular}

According to BORGES et al. (2007), the area close to stations 1 and 3 is considered polluted by $\mathrm{Cu}$ and $\mathrm{Pb}$, and this problem has been exacerbated by the degradation of the vegetation in this area, which has modified the accumulation of organic-matter, possibly also altering the processes of the accumulation of metals. It is characterized as a region of low depth, high ammonia levels and low dissolved oxygen, with poor circulation and high inflow of domestic sewage, in addition to the residues from the refinery. The chronic toxicity was evident in ELU and SWI tests.

- Northeast Sector: This region comprises Paquetá Island and a broad mangrove area. It includes stations $6,7,8$ and 9. Acute toxicity was observed in the sediments from stations 6 and 8. Stations 7, 8 and 9 exhibited chronic toxicity in the three experiments. In this area, specifically in station 7, the interstitial water had lower $\mathrm{NH}_{3}$ concentrations.

In an overview, it was observed that all the stations sampled showed chronic toxicity and the PW bioassay was the most influenced by un-ionized ammonia. There is a dynamic equilibrium between the dissolved compounds in interstitial water and those adsorbed in the solid phase of the sediment, called Equilibrium Partitioning - EqP (CHAPMAN et al., 2002), which is dependent on environmental conditions and the intrinsic characteristics of each substance, and that helps to explain the effects of each contaminant on the biota. Interstitial water tests tend to be more sensitive when there is contamination by metal, probably because metals may be soluble in the water column, allowing these contaminants to be accumulated by the embryos (CESAR et al., 2004). In some cases, SWI can provide a better agreement with chemical contaminant levels and changes in the macroinvertebrate community (CESAR et al., 2004), because the chemical activity at the sediment-water interface directly affects the quality of the adjacent water column. Thus, beyond the sediments, the adjacent water column and the local biota are being affected, due to local contamination.

Geochemical studies should be conducted to complement the present study. However, the present data provide important evidence that much GB sediment is detrimental to aquatic life (whether the result of chemical contaminants or ammonia). At the stations sampled, the sediment quality of GB was generally poor, probably due to human activities conducted around the GB and to the chemicals discharged from industrial and municipal sources.

Also, sediment toxicity has some additional implications for the GB areas where mangroves are still present: a) these ecosystems are important, due to their productivity and the economic and ecological services they provide. At the same time, they are highly sensitive to the effects of human activities, thus, these areas should be protected from pollution and, if they have already been contaminated, they need to be restored.

There is also a need to establish connections or causal links between contamination, geochemical aspects, toxicity and their effects on benthic communities. The comprehension of the effects on benthic communities also needs to be enhanced as well as the fate of contaminants in GB, including degradation, immobilization, bioaccumulation and exportation to other ecosystems. Meanwhile, the work of researchers should not be restricted to specific diagnoses of environmental quality, but should also include continuous monitoring, permitting the introduction and evaluation of corrective measures, mitigation, control and prevention. Also, the national environmental legislation should be fully applied, for the purpose of controlling the sources of pollutants and promoting a recovery of the environmental quality of Guanabara Bay. 


\section{ACKNOWLEDGEMENTS}

We wish to acknowledge our debt to the staff of the Aquatic Ecotoxicology Laboratory of Santa Cecilia University and the Geochemistry Laboratory of the UFF for their logistic support; as also to Miss Clarissa C. Skrepnek for the preparation of the map and to the anonymous reviewers for their suggestions.

\section{REFERENCES}

ABESSA, D. M. S.; CARR, R. S.; RACHID, B. R. F.; SOUSA, E. C. P. M.; HORTELANI, M. A.; SARKIS, J. E., 2005. Influence of a Brazilian sewage outfall on the toxicity and contamination of adjacent sediments. Mar. Pollut. Bull., v. 50, p. 875-885, 2005.

ABESSA, D. M. S.; CARR, R. S.; SOUSA, E. C. P. M RACHID, B. R. F.; ZARONI, L. P.; PINTO, Y. A.; GASPARRO, M. R.; BÍCEGO, M. C.; HORTELLANI, M. A.; SARKIS, J. E. S.; MUNIZ, P. Integrative ecotoxicological assessment of a complex Tropical Estuarine System. In: HOFFER, T.N. (Ed.) Marine Pollution: New Research. New York: Nova Science Publishers, 2008. Chapter 4, p.125-159.

ABNT - Associação Brasileira de Normas Técnicas. Norma Técnica NBR No. 15350: 2006. Ecotoxicologia aquática - toxicidade crônica de curta duração - método de ensaio com ouriço-do-mar (Echinodermata; Echinoidea). São Paulo: $2006.17 \mathrm{p}$

ADAMS, W. J.; KIMERLE, R. A.; BARNETT, J. W. Sediment quality and aquatic life assessment. Environ. Sci. Technol., v. 26, n. 10, p. 1864-1875, 1992.

AMADOR, E. S. Baía de Guanabara e ecossistemas periféricos: Homem e Natureza. Ribeirão Preto, SP: Reproarte Gráfica e Editora, 1997. 539 p.

ANDERSON, B. S.; HUNT, J. W.; PHILIPS, B. M.; FAIREY, R.; PUCKETT, H. M.; STEPHENSON, M.; TABERSKI, K.; NEWMAN, J.; TJEERDEMA, R. S Influence of a sample manipulation on contaminant flux and toxicity at the sediment-water interface. Mar. environ. Res., v. 51, p. 191-211, 2001.

BAPTISTA-NETO, J. A.; SMITH, B. J.; McALLISTER, J. J. Heavy metal concentrations in surface sediments in a nearshore environment, Jurujuba Sound, Southeast Brazil. Environ. Pollut., v. 109, p. 1-9, 2000.

BAPTISTA-NETO, J. A.; CRAPEZ, M.; VILELA, C. G.; McALLISTER, J. J. Concentration and bioavailability of heavy metals in sediments from Niterói harbour/S.E. Brazil. J. coast. Res., v. 21, n. 4, p. 811-817, 2005.

BAPTISTA-NETO, J. A.; GINGELE, F. X.; LEIPE, T BREHME, I. Spatial distribution of heavy metals in surficial sediments from Guanabara Bay: Rio de Janeiro. Braz. Environ. Geol., v. 49, p. 1051-1063, 2006

BERTOLETTI, E; BURATINI, S. V.; PRÓSPERI, V. A ; ARAÚJO, R. P. A; WERNER, L. I. Selection of relevant effect levels for using bioequivalence hypothesis testing. J. Braz. Soc. Ecotoxicol., v. 2, n. 2, p. 139-145, 2007.

BORGES, A. C.; DIAS, J. C.; MACHADO, W.; PATCHINEELAM, S. R. Distribuição espacial de ferro, cobre e chumbo em sedimentos de manguezal em um gradiente de degradação na baía de Guanabara (Estado do Rio de Janeiro). Química Nova, v. 30, p. 66-69, 2007

CARR, R. S.; NIPPER, M. G. (Ed.). Porewater toxicity testing: biological, chemical, and ecological considerations. Pensacola, FL.: SETAC Press, 2003. $346 \mathrm{p}$.

CARR, R. S.; BIEDENBACH, J. M.; NIPPER, M. G. Influence of ammonia, $\mathrm{pH}$, dissolved organic carbon and other potentially confounding factors on sea urchin porewater toxicity tests. Archs environ. Contamin. Toxicol., v. 51, p. 573-579, 2006.

CARREIRA, R. S.; WAGENER, A. L. R.; READMAN, J. W. Sterols as markers of sewage contamination in a tropical urban estuary (Guanabara Bay, Brazil): spacetime variations. Estuar. coast. Shelf Sci., v. 60, p. 587598, 2004.

CESAR, A.; MARÍN, A.; MARÍN-GUIRAO, L.; VITA, R. Amphipod and sea-urchin tests to assess the toxicity of Mediterranean sediments: the case of Portmán Bay. Scientia mar., v. 68, p. 205-213, 2004.

CETESB - Companhia de Tecnologia de Saneamento Ambiental. Água do mar: teste de toxicidade crônica de curta duração com Lytechinus variegatus LAMARCK, 1816 (Echinodermata: Echinoidea) método de ensaio. Norma técnica L5.250. São Paulo, 1999. $22 \mathrm{p}$.

CETESB - Companhia de Tecnologia de Saneamento Ambiental. Relatório de qualidade das águas litorâneas do estado de São Paulo: balneabilidade das praias 2006 - São Paulo, 2007. CD ROM (365 p.). (Série: Relatórios/Secretaria de Estado do Meio Ambiente, São Paulo, ISSN 0103-4103).

CHAPMAN, P. M.; WANG, F.; GERMANO, J. D.; BATLEY, G. Pore-water testing and analysis: the good, the bad and the ugly. Mar. Pollut. Bull., v. 44, p. 359366, 2002.

ENVIRONMENT CANADA. Canadian sediment quality guidelines for the protection of aquatic life. Summary tables, 1999. < http://www.ec.gc.ca>.

KFOURI, P. B. P.; EICHLER, B. B.; EICHLER, P. B.; PEREIRA, E. R. M.; FIGUEIRA, R.; ABESSA, D. M. S.; SOUSA, E. C. P. M. Toxicidade dos sedimentos da Baía de Guanabara - RJ determinada pela ocorrência das associações de foraminíferos bentônicos e testes com anfípodos Tiburonella viscana. In: CONGRESSO SOBRE PLANEJAMENTO E GESTÃO DAS ZONAS COSTEIRAS DOS PAÍSES DE EXPRESSÃO PORTUGUESA, 2./ CONGRESSO DA ASSOCIAÇ̃̃O BRASILEIRA DE ESTUDOS DO QUATERNÁRIO, 9./ CONGRESSO DO QUATERNÁRIO DOS PAÍSES DE LÍNGUA IBÉRICA, 2., 2003, Recife, PE. Anais... 2003, p. 1-4.

KJERFVE, B.; RIBEIRO, C. H. A.; DIAS, G. T. M.; FILIPPO, A. M.; QUARESMA, V. S. Oceanographic characteristic of an impacted coastal bay: Baía de Guanabara, Rio de Janeiro, Brasil. Cont. Shelf Res., v. 17, p. 1609-1643, 1997.

LOURENCO, S. O.; BARBARINO, E.; NASCIMENTO, A.; FREITAS, J. N. P.; DINIZ, G. S. Tissue nitrogen and phosphorus in seaweeds in a tropical eutrophic environment: What a long-term study tells us. J. appl. Phycol., v. 18, p. 389-398, 2006.

MACIEL-SOUZA, M. C.; MACRAE, A.; VOLPON, A. G. T.; FERREIRA, P. S.; MENDONÇA-HAGLER, L. C., Chemical and microbiological characterization of mangrove sediments after a large oil-spill in Guanabara Bay - RJ - Brazil. Braz. J. Microbiol., v. 37, p. 262266, 2006.

MARQUES-JÚNIOR, A. N.; CRAPEZ, M. A. C.; BARBOZA, C. D. N. Impact of the Icaraí sewage outfall in Guanabara Bay, Brazil. Braz. Arch. Biol. Technol., v. 49 , n. 4 , , p. 643-650, 2006.

MELO, S. L. R.; ABESSA, D. M. S. Testes de toxicidade com sedimentos marinhos utilizando anfípodos. In: NASCIMENTO, I. M.; SOUZA, E. C. P. M.; NIPPER, M. (Ed.). Métodos em ecotoxicologia marinha: Aplicações no Brasil. São Paulo: Artes Gráficas e Indústria, 2002. p. 163-178.

MENICONI, M. F. G.; GABARDO, I. T.; CARNEIRO, M. E. R.; BARBANTI, S. M.; DA SILVA, G. C.; MASSONE, C. G. Brazilian oil spills chemical characterization - case studies. Environ. Forensis, v. 3, p. 303-321, 2002. 
NIPPER, M. G. The development and application of sediment toxicity tests for regulatory purposes. In: WELLS, P. G.; LEE, K.; BLAISE, C. Microscale testing in aquatic toxicology: advances, techniques and practice. Boca Raton, FL: CRC Press, 1997. v. 43, p. 631-646.

PARANHOS, R.; PEREIRA, A. P.; MAYR, L. M. Diel variability of water quality in a tropical polluted bay. Environ. Monit. Assess., v. 50, p. 131-141, 1998.

PRÓSPERI, V. A.; ARAÚJO, M. M. S. Teste de toxicidade crônica com Lytechinus variegatus, Lamarck 1816, e Echinometra lucunter, Linnaeus 1758 (Echinodermata: Echinoidea). In: NASCIMENTO, I. M.; SOUZA, E. C. P. M.; NIPPER, M. (Ed.). Métodos em Ecotoxicologia marinha: Aplicações no Brasil. São Paulo: Artes Gráficas e Indústria , 2002. p. 99-110.

RIBEIRO, C. H. A.; KJERFVE, A. E. B. Anthropogenic influence on the water quality in Guanabara Bay, Rio de Janeiro, Brazil. Reg. environ. Changes, v. 3, p. 13-19, 2002.

SARDA, N.; BURTON, G. A. Ammonia variation in sediments: spatial, temporal and method-related effects. Environ.Toxicol. Chem., v. 14, n. 9, p. 1499-1506, 1995.

SWARTZ, R. C.; DEBEN, W. A.; JONES, J. K. P.; LAMBERSON, J. O.; COLE, F. A. Phoxocephalid amphipod bioassay for marine sediment toxicity. SYMPOSIUM ON AQUATIC TOXICOLOGY AND HAZARD ASSESSMENT, 1985. Proceedings... v. 7, p. 284-307, 1985.

U.S. EPA - United States Environmental Protection Agency. Evaluation of dredged material proposed for ocean disposal - testing manual. Army Corps of Engineers, EPA 503/8-91/001, 1991. $214 \mathrm{p}$
U.S. EPA - United States Environmental Protection Agency. Methods for assessing the toxicity of sedimentassociated contaminants with estuarine and marine amphipods. 1994. (EPA/600/-94/025).

U.S. EPA - United States Environmental Protection Agency. Short-term methods for estimating the chronic toxicity of effluents and receiving waters to west coast marine and estuarine organisms. First edition, 1995. (EPA/600/R-95-136).

VILELA, C. G.; BATISTA, D. S.; BAPTISTA-NETO, M. C.; McALLISTER, J. J. Benthic foraminifera distribution in highly polluted sediments from Niterói Harbor (Guanabara Bay), Rio de Janeiro, Brazil. An. Acad. Bras. Ciênc., v. 76, n. 1, p. 161-171, 2004.

WEST INC; GULLEY, D. TOXSTAT 3.5. Wyoming: University of Wyoming, 1995.

WINGER, P. V.; LASIER, P. J. A Vacuum-operated porewater extractor for estuarine and fresh-water sediments. Archs environ. Contamin. Toxicol., v. 21, n. 2, p. 321324, 1991.

ZAKREWSKI, S. F. Principles of environmental Toxicology. American Chemical Society, 1991. 270 p.

ZAR, J. H. Biostatistical analysis. 3 rd. ed. Englewood Cliffs, NJ: Prentice Hall, 1996. 662 p.

(Manuscript received 03 March 2009; revised 25 November 2009; accepted 05 March 2010) 